\title{
Nogle betragtninger over den historiske baggrund for hjemmetyskheden i Nordslesvig - specielt med henblik på Tønder og Højer
}

Af $H$. V. Gregersen

Afstemningskortet fra 1920

Resultatet af folkeafstemningerne den 10. februar og 14. marts 1920 er ofte blevet taget til indtægt for en vurdering af de whistoriske kræfter«, der har skabt skellet mellem dansk og tysk inden for Sønderjyllands befolkning, og det er utvivlsomt med rette, når afstemningsresultaterne har givet anledning til sådanne overvejelser. Det klareste billede af de forskelle, der lader sig påvise fra egn til egn, gives uden sammenligning af folkeafstemningskortet fra 1920, og det kan derfor anses for at være det bedst egnede udgangspunkt for en undersøgelse af den historiske baggrund for den nationalpolitiske udvikling i vort grænseland.

Efter 1. verdenskrig var folkenes selvbestemmelsesret det ideal, efter hvilket grænserne skulle drages, og det ligger uden for al diskussion, at ingen af det daværende Tysklands nye grænser blev afsat med en større respekt for selvbestemmelsesretten end den nye dansk-tyske grænse. Sindelaget, således som det kom til udtryk ved afstemningen, var afgørende, ikke de sproglige forhold, hvilket ses af, at grænsen blev draget gennem egne med overvejende dansk-sønderjysk dialekt. Dette sindelagsskel hænger så - som så ofte påpeget - sammen med den kirke- og skolesprogsgrænse, der var en arv fra reformationstiden. Den dansk-sønderjyske befolkning syd for denne grænse havde nemlig takket være kirken og skolen fået tysk kultursprog, og det har åbenbart for sindelaget vejet tungere end dagligdagens dansk-sønderjyske dialekt.

Selv om der i det danske folk var et flertal for, at landegrænsen blev så retfærdig som mulig, har afstemningskortet alligevel iøjnefaldende 
"skønhedspletter«, og det skyldes først og fremmest det høje stemmetal til fordel for Tyskland $\mathrm{i}$ Tønder by, Højer flække og landsogn, samt i Ubjerg. At købstæderne Åbenrå og Sønderborg, samt jernbanecentret Tinglev også havde tyske flertal, men af en ringe størrelse, må henregnes under det faktum, at købstæder og bymæssige bebyggelser har en langt mere labil befolkning end de rene landdistrikter. ${ }^{1}$

I købstaden Tønder med kun 23\% danske stemmer og i flækken Højer med $27 \%$ viser de høje tyske stemmetal derimod, at der inden for den fastboende befolkning har været tale om et overvejende tysk sindelag. Når de to byer alligevel kom til Danmark, er det helt indlysende, at det skyldes de geografiske forhold, bestemt af Vidåens forløb.

Martin Hammerich har udtrykt det i disse ord: "Havde disse sogne ikke ligget nord for den $\mathrm{i}$ alle henseender naturlige grænse, som på sin vestlige strækning tilmed går i nordlig retning, og havde navnlig Tø̛nder ikke ligget således, at en adskillelse fra det både mod vest, nord og øst tilgrænsende område, der utvivlsomt måtte tilfalde Danmark, ville have været yderst uheldigt for oplandet, ødelæggende for Tønder by og i grænseteknisk henseende uholdbar, var Tønder by med sit dengang sikkert tysksindede flertal utvivlsomt aldrig blevet inddraget under den 1. zone, der ønskedes betragtet som en helhed. Forholdet synes så klart, at den internationale kommission, dersom denne frit kunne have draget en grænse, ikke blot slavisk følgende stemmeflertallet i de enkelte

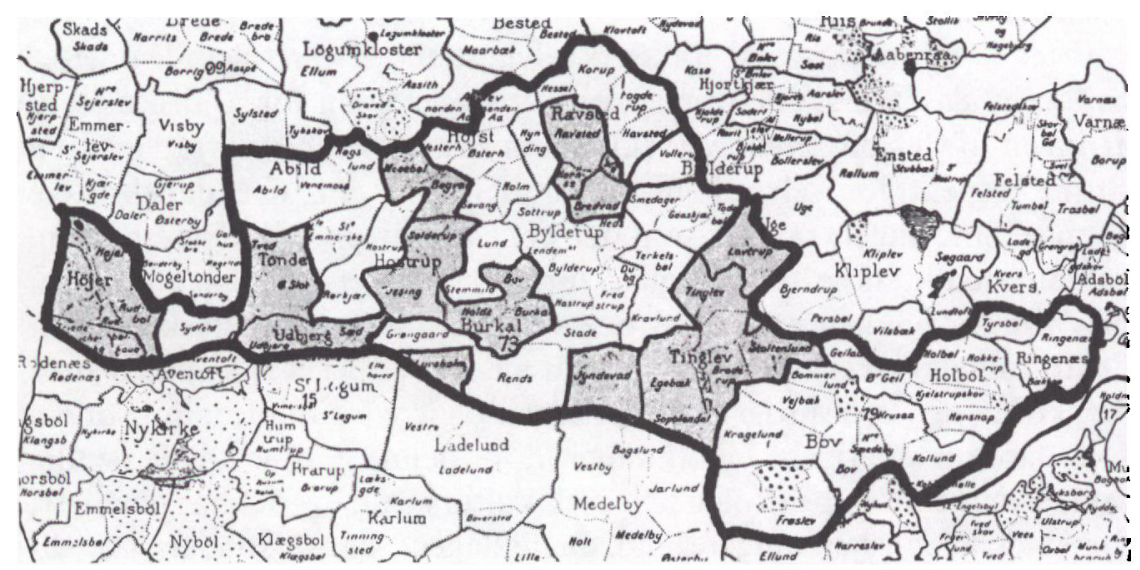

Tiedje-baltet nord for vor nuvarende landegranse. Man ser, hvorledes den nordlige afgransning gennemskarer Mogeltender, Abild, Hajst, Bjolderup, Uge, Kliplev og Kvars sogne. Omrderne med tysk flertal er serligt markerede. 
sogne, men tillige, som der står i fredstraktatens artikel 110: »under hensyn til de pågældende steders særlige geografiske og økonomiske forhold «, må antages at have draget den syd om de nævnte sogne «. ${ }^{2}$ Så vidt Martin Hammerich, den ledende $i$ den danske jordkamp $i$ Nordslesvig i tiden mellem de to verdenskrige.

Når man fra dansk side fastholdt 1 . zones udelelighed, skete det ud fra de grundige undersøgelser af de nationale forhold inden for selve grænseområdet, som H. V. Clausen havde foretaget. Hans forslag til den såkaldte "Clausen-linje« var - som han udtrykte det - fremsat, fordi det ville blive »en grænse dannet af natur og historie $i$ forening. Til begge sider for denne linje (d.v.s. nord og syd herfor) findes Sønderjyllands største hede- og mosestrækninger, vestpå fortsat ud til havet i meget tyndt befolkede engdrag og marskflader og østpå, hvor heden slipper op, fortsat $\mathrm{i}$ den dybe dal med sine enge og søer $\mathrm{i}$ bunden, gennem hvilken Krusåen flyder ud til Flensborg fjord, hvor den danner Kobbermøllebugten, ... den korteste linje, der kan drages over Slesvig fra Østersø til Vesterhav, ... vigtig især, fordi den ikke blot er naturlig frem for nogen anden, men også fordi den i de sidste århundreder har været vor virkelige kulturgrænse «. ${ }^{3}$

Hvor rimelig en grænsedragning $i$ henhold til »en-bloc«-princippet (d.v.s. 1. zone, betragtet som en helhed) end måtte synes at være, fremkom der alligevel et tysk modforslag, udarbejdet af det tyske udenrigsministeriums sagkyndige med hensyn til Nordslesvig, den i forvejen kendte præst og publicist Johannes Tiedje.

Efter folkeafstemningen den 14. marts 1920 i 2 . zone (syd for den nuværende landegrænse) udarbejdede Johannes Tiedje et forslag, ifølge hvilket der afgrænsedes et »bælte« tværs over det sydlige Nordslesvig, omfattende Tønder-Højer-hjørnet, Slogs herred og sognene ind imod Flensborgs inderfjord, det såkaldte "Tiedje-bælte«, inden for hvilket der kunne mønstres et knebent tysk flertal (på ca. 50 stemmer) samtidig med, at man kunne hævde, at der ville blive omtrent lige store mindretal på hver side af grænsen, dersom dette "bælte« blev overladt Tyskland.

Det var alene det tyske stemmetal i Tønder og Højer med landsogn, samt Ubjerg, der var afgørende for det knebne tyske flertal inden for "Tiedje-bæltet«, derimod ikke de atten små, tyndt befolkede afstemningsdistrikter inden for »bæltet«, der - bortset fra Tinglev sogn intetsteds medførte et tysk flertal inden for deres sogn som helhed. Fra dansk side måtte det derfor findes urimeligt, dersom Tønder-Højerhjørnets tyske flertal skulle få virkninger helt over til Flensborg fjord. Hvad der dog var endnu værre, var »bæltets« helt vilkårlige nordlige 
afgrænsning, der ikke tog hensyn til foreliggende geografiske forhold og tilmed i hele syv tilfælde overskar gamle, hævdvundne sognegrænser.

På denne baggrund kan det undre, at "Tiedje-bæltet« fik en så forholdsvis stor vægt $i$ datidens tyske grænseagitation, ikke mindst fordi der samtidig i Danmark var kredse, der hævdede, at den nye grænse ikke havde taget hensyn til, at valgene til den nordtyske rigsdag i 1867 havde givet et - ganske vist knebent - dansk flertal til en linje syd om Flensborg, og at grænsedragningen $i 1920$ derfor i virkeligheden havde »belønnet « det tyske herredømme over Sønderjylland mellem 1864 og $1920 .^{4}$

Diskussionen om betimeligheden af den stedfundne grænsedragning er vel alt $\mathrm{i}$ alt forstummet, og på baggrund af, hvad det tyske folk har måttet opleve af grænse- (og folke-)forskydninger efter 2. verdenskrig, er der vel i vor tid også i tyske kredse forståelse for rimeligheden af grænsedragningen i 1920. Det tyske mindretals anerkendelse i 1945 af den dansk-tyske grænse kan ses som et udtryk for denne forståelse. ${ }^{5}$

\section{"Historiens rest"}

Tilbage til afstemningskortet. Det tyske stemmeflertal i Tønder, Højer og Ubjerg markerer sig her særligt skarpt, fordi enklavesognet Møgeltønder mellem Tønder og Højer fremviser et dansk flertal af samme størrelse, ligesom også grænseskellet findes skarpest aftegnet mellem Møgeltønder og Aventoft (med hhv. 86 og 16\% danske stemmer). Ingen kan være i tvivl om, at det er »historiens røst«, der her lyder.

Dette har man også længe været klar over. Først og fremmest var man klar over, at selve delingslinjen mellem Nord- og Sydslesvig i hovedsagen var bestemt af den århundredgamle kirke- og skolesprogsgrænse, der siden 1840 tillige var retssprogets grænse, altsammen forhold, der efter 1864 blev ændret i tysk favør. Det var disse gamle sprogligt-kulturelle skel, der delte Sønderjylland i to dele, og ikke grænsen for dagligdagens dansk-sønderjyske dialekt.

Forklaringen på tyskhedens udbredelse i selve Nordslesvig har været knap så entydig. Man har diskuteret, hvad det var, der førte til »hjemmetyskheden«. Med denne glose betegnede man i 1848 fra dansk side de mennesker af hjemlig herkomst, som til trods for, at de talte deres hjemstavns dansk-sønderjyske dialekt, foretrak den administrative forbindelse med Holsten frem for med kongeriget Danmark, og endog som noget helt nyt og hidtil ukendt - var villige til at gå med til en indlemmelse af deres hjemstavn i det nye Tyskland, som søgtes dannet i 1848.6 
Ønsket om at bevare forbindelsen med Holsten er med rette blevet opfattet som et konservativt træk, som et udtryk for en særlig slesvigholstensk følelse, men det er samtidig også et revolutionært træk, eftersom det betød en total ændring af de bestående politiske tilstande.?

Det kan dog anses for givet, at den enkelte hjemmetysker ikke har gjort sig så vidtgående tanker. Adskillig større betydning bør der nok tillægges de erhvervsmæssige interesser, som ikke mindst de større bønder og bykøbmænd kunne have af forbindelsen sydpå. Efter statsbankerotten 1813 var Hamburg blevet den magnet, der trak handelen sydpå, og længe inden var studehandelen gået i samme retning. Menigmand vidste, at tyske møntsorter var at foretrække frem for de kongerigske efter statsbankerottens onde år.

Alle, der havde råd til det, borgere såvel som bønder, sendte de bedre begavede af deres drenge til uddannelse sydpå. Det skete ikke alene i 1800-årenes begyndelse, men også langt tidligere, idet et kendskab til tysk blev anset for at være en vigtig forudsætning for en fremtidig karriere. Også studievejen gik mod syd til tyske universiteter.

Alle disse forhold under ét førte til, at der hos mange sønderjyder herskede en vis stolthed over at være »slesvigere«, over at tilhøre »det hertugelige«, alt imens kongerigets indbyggere - især »jyllændere«, den tids fremmedarbejdere i Sønderjylland - ansås for at være mere tilbagestående. Denne indstilling ændredes først efter midten af 1800årene, da man nordfra kunne fremvise grundloven af 1849 , højskolerne, andelsbevægelsen etc.

Det var forhåndssympatien for »det hertugelige«, den augustenborgske hertug i 1840rne kunne udnytte til sit personlige anliggende, idet menigmand ikke gjorde sig tanker om, at der var langt fra den gottorpske hertugslægt til augustenborgerens familie. Alle, der ejede noget, havde dokumenter liggende om deres ejendom, og her kunne man til indledning læse, at øvrigheden - også den kongelige efter inkorporationen 1720-21 - repræsenterede »die Herzogthümer Schleswig, Holstein etc ${ }^{8}{ }^{8}$

Dette være sagt, fordi man ofte har fremhævet det gottorpske styre, der mellem 1580 og 1713/20 regerede Åbenrå, Løgumkloster og Tønder amter, som en væsentlig forudsætning for den hjemmetyskhed, der kendes $\mathrm{i}$ årene efter $1830 \mathrm{og}$ da navnlig i 1840rne med 1848 som klimaks.

Man finder denne opfattelse hos Peder Lauridsen i værket Da Sønderjylland vaagnede: »Indtil 1720 havde Aabenraa tilhørt den gottorpske Hertug, og denne Fyrstes Had til det danske Kongedømme havde 
ogsaa sat sine Spor hos hans nordslesvigske Undersaatter; endnu fire Slægtled senere var den gottorpske Særfølelse ikke vadsket helt ud af Sindene, Borgernes Statskærlighed kunde anfægtes, og det var kun skrantne Kongelys, der groede op omkring Brundlund Slot«.9

På en tilsvarende måde har den hjemmetyske historiker fra Tønder, Ludwig Andresen, opfattet det gottorpske styre i Nordslesvig, ${ }^{10}$ og det er da også uomtvistet, at hjemmetyskheden, således som den manifesterede sig ved folkeafstemningen i 1920, stod stærkest $i$ hovedparten af de sogne, der før 1713/20 havde hørt under Gottorp. Men der er også undtagelser, der modsiger denne opfattelse, f.eks. Varnæs med $94 \%$ danske stemmer! Det kunne tyde på, at også en personlig påvirkning på lokalt plan har spillet en rolle for valget mellem dansk og tysk.

Tanken om gottorperstyret som en forudsatning for hjemmetyskheden blev $i$ et svar til Ludwig Andresen afvist af Troels Fink, der med rette kunne hævde, at det aldrig er lykkedes at påvise en direkte forbindelse mellem gottorpsk statspatriotisme før $1720 \mathrm{og}$ den politiske slesvig-holstenisme efter 1830-40."1

Det, der nok har vejet tungest til fordel for en forhåndsindstilling til "det hertugelige « og en forhåndsaccept af, at det tyske sprog nu engang hørte sammen med den herskende øvrighed, er vel den kendsgerning, at der $\mathrm{i}$ forbindelse med inkorporationen 1720-21 ikke fandt et egentligt brud sted med tidligere tiders tilstande. Nok var den gottorpske hertug fjernet og med ham store dele af overøvrigheden, men ellers fortsatte styret som hidtil. Patriotismen kunne derfor overalt i hertugdømmet samle sig om kongen som helstatens øverste overhoved. Denne fyrste- og statstroskab kom tydeligt til udtryk efter slaget på Københavns red i 1801 og under krigen mod England 1807-14. Da kunne der ikke spores forskel på de tidligere kongelige og gottorpske andele af Sønderjylland. Men det betød ikke, at folk fra hertugdømmet ønskede at blive slået $\mathrm{i}$ hartkorn med dem fra kongeriget! Kongeåen og Kolding fjord føltes helt klart som skel, der delte befolkningen mod nord og syd.

Den særlige udvikling i Sønderjylland havde nemlig i årenes løb skabt et "klima«, der var kendetegnet af »søndenvinden«, af påvirkningerne sydfra. Selv i sognene med en overvejende anti-slesvigholstensk indstilling var folk almindeligvis ivrige efter at betone, at de var »slesvigere«, eventuelt »dansk-slesvigere«, men »danskere« var de ikke! En århundredlang udvikling går nu engang ikke sporløst hen over en befolkning. ${ }^{12}$

De her fremførte synspunkter galder situationen, som den har fore- 
ligget frem til det afgørende år 1848. Dette er vigtigt at fastslå, når der indledningsvis er tale om en bedømmelse af hjemmetyskhedens styrke ud fra de stemmetal, der fremkom ved folkeafstemningen i 1920. Fremmedherredømmets 56 år - fra 1864 til 1920 - har selvsagt også øvet sin indflydelse på afstemningsresultatet. Dels fandt der i dette tidsrum en indvandring sted sydfra, som helt naturligt har været med til at præge stemmetallene; især for afstemningens udfald i købstæderne og de bymæssige bebyggelser har dette - som tidligere fremhævet - betydet et udslag i tysk retning. ${ }^{13}$ Men dels opnåede tyskheden også en vis landvinding i dette tidsrum, fordi mange hjemmehørende - lige fra lærere og ansatte i offentlige kontorer til kirkegårdsgravere og vejmænd - på grund af deres ansættelsesforhold stod i et afhængighedsforhold til øvrigheden. Når det tyske stemmetal sank ved valgene efter 1920 , skal det næst efter bortvandring også ses som et udtryk for, at en stor del fra denne gruppe igen fandt sin plads inden for danskheden. Det hører nu engang med til grænselandsbefolkningens vilkår, at konjunkturer også har spillet en rolle for valget mellem dansk og tysk. Udviklingen har dog vist, at »omsindelsen« for de fleste har været varig; ofte gav den sig rørende udtryk $i$ glæden over at være dansk. ${ }^{14}$

\section{Claus Eskildsen og tyskheden $i$ Tonder}

Den egentlige skønhedsplet på kortet over folkeafstemningen i 1920 set fra dansk side - er som nævnt Tønder-Højer-hjørnet, og det er på baggrund af det anførte naturligt at spørge, hvorfor det tyske stemmetal netop markerer sig så skarpt her.

Claus Eskildsen, seminarielærer i Tønder, har i sin tid stillet sig samme spørgsmål og gør med rette opmærksom på, at helstatspatriotismen i begyndelsen af 1800-årene var lige så fremtrædende i Tønder som $\mathrm{i}$ de øvrige nordslesvigske købstæder. "Liebe fürs Vaterland knüpfet ein schönes Band durchs ganze Land!«, læser man i Tondersches Intelligenz Blatt for den 29. januar 1818. Det officielle sprog øvrighedens, kirkens og skolens sprog - var i Tønder by som i de øvrige nordslesvigske købstæder tysk; men det gav ingen skår $i$ tidens udbredte loyalitetsfølelse.

Men derefter skriver Claus Eskildsen: "Et Vendepunkt med et brat og radikalt Omslag sætter ind med Aaret 1840. Fra nu af gaar »Tond. Int. Blatt« i god Overensstemmelse med det toneangivende Borgerskab med Slesvig-Holsteinismen gennem tykt og tyndt, og Tønder fremtræder $\mathrm{i}$ Tidens Løb som den mest tysksindede By, uden en mærkbar dansk Opposition som i de andre nordslesvigske Købstæder. Hvad er 
Aarsagen hertil? Det skyldes ikke Blodsbaand, der kunde vise sydpaa. Vælger man som Eksempel de tysksindede Raadmænd, der blev afskedigede 1851, saa var Detlef Jensen Angel Søn af en Angelbo, Oluf Hanquist Søn af en Svensker fra Vestervig i Smaaland, F. J. Radoor Sønnesøn af en Fynbo, og Nis Jürgensen var fra Haderslev; Borgmesteren hed Broder Knudsen, og den afskedigede Kæmner og Formand for Deputeretkollegiet Graus Grausen Wedersøe var Søn af Gravers Graversen fra Vedersø i Vestjylland. Det skyldtes heller ikke Modersmaalet, thi »det er desværre sandt, at Omgangssproget i Tønder er en dansk Jargon, der har saa faste Rødder her, at selv Ultra-SlesvigHolstenere plejer den omhyggeligt og bibeholder den i deres Hjem og Omgang« (Tond. Intell. Blatt 2. sept. 1841).

Lidt senere hedder det i Claus Eskildsens afhandling: "At Tønder og Aabenraa blev mere tyske end de andre [Byer], skyldtes den Atmosfære, der var fremkaldt ved 150 Aars gottorpsk Herredømme, idet Modsætningen mellem gottorpsk og kongeligt i Underbevidstheden blev til en tysk-dansk Modsætning. At Tønder senere blev mere rent tysksindet end Aabenraa, skyldtes dels det stærkt tyskprægede Opland, dels Aarhundredernes lybske Ret og dels den Omstændighed, at der i Tønder ikke fremstod en Mand af Frederik Fischers Støbning. Man maa overhovedet ikke undervurdere Enkeltpersoners Indflydelse i denne skelsættende Tid .... (15 $^{\text {s }}$

Det var i anledning af byjubilæet $\mathrm{i}$ 1943, at Claus Eskildsen skrev disse linjer, og når de er blevet citeret, skyldes det, at man langt hen ad vejen har al grund til at give Claus Eskildsen ret. Det er rigtigt, at Tønders udvikling i årene forud for den nationale vakkelse i 1840rne ikke adskilte sig fra, hvad man kender fra de andre nordslesvigske byer, og det er rigtigt, at det tyske sindelag ikke skyldtes indvandring sydfra, og at byens dagligsprog derfor helt naturligt var den dansksønderjyske dialekt. Utvivlsomt er det også rigtigt, at hovedårsagen til Tønders høje tyske stemmetal nok skal søges i det forhold, at man her ikke fik en dansksindet foregangsmand, der kunne vinde sine medborgere for danske synspunkter. Tønder oplevede derfor ikke en egentlig national vækkelse.

Alt dette er ræsonnementer, der lader sig nøje kontrollere, og som er helt naturlige, eftersom hjemmetyskheden jo netop skriver sig fra den nationale vækkelse i 1840rne som en tysk pendant til det danske sindelag, flertallet af befolkningen i Nordslesvig gav udtryk for. Men når Claus Eskildsen går videre og både anfører »150 års gottorpsk 
herredømme « og ovenikøbet "århundredernes lybske ret « som medvirkende til, at Tønder blev den mest tysksindede købstad i Nordslesvig, er der helt tydeligt tale om en påvirkning fra Ludwig Andresens skrifter om hjemmetyskhedens opståen, og dennes resultater er jo ikke forblevet uimodsagte. ${ }^{16}$ Det er unægteligt noget selvmodsigende, når Claus Eskildsen først redegør for den loyale stemning over for kongehuset i helstatstiden og derefter alligevel anfører de "150 års gottorpske herredømme« og dertil endda Tønders lybske stadsret.

Alligevel er der nok noget om, at de abstrakte begreber, der nævnes, "atmosfære" og "underbevidsthed «, har skabt den stemning hos tøndringerne, der forte dem over i tyskheden. Jeg skal i det følgende gøre et forsøg på at vise, hvad der efter min opfattelse er årsagen til, at Tønder og Højer i 1920 så klart gav udtryk for, at der her herskede et andet »klima« end i det øvrige Nordslesvig.

\section{Navneformerne Tonder, Mogeltonder og Lilletonder}

Bynavnet Tonder er et af de ældste danske stednavne, der kendes, idet det i 1130 af den arabiske geograf Idrisi under navneformen "Tundira" omtales som "en ankerplads $\mathrm{i}$ læ for vindene og omgivet af bygninger «. ${ }^{17}$ Der kan derfor næppe være tvivl om, at Tønder allerede har eksisteret på vikingetiden. Når vi $\mathrm{i}$ vor tid har både et Tønder og et Møgeltønder, så er dette navnesammenfald kun et af flere vidnesbyrd om, at stednavne i gammel tid godt kunne galde forskellige lokaliteter inden for et snævrere område. ${ }^{18}$

Oprindeligt brugtes Tønder om begge lokaliteter. Når f.eks. Ribebispens kirke i »Tønder « findes nævnt i 1214, så sandsynliggør omtalen af marknavnet Lundevrå i det pågældende kildested, at der er tale om Møgeltønder. ${ }^{19}$ Først hen i middelalderen blev det almindeligt at skelne mellem de to lokaliteter. Bispeborgens by fik navnet Møgeltønder (1288: Mykæltundær) og kendes siden kun under denne navneform. Købstaden Tønder beholdt derimod $\mathrm{i}$ regelen sit navn, men kaldtes også ofte til forskel fra Møgeltønder (»Storetønder«) med den mere ydmyge betegnelse "Lilletønder" (1313: Lytlætundær). Denne ejendommelige navngivning skyldes ikke, således som det ofte er blevet sagt, ${ }^{20}$ at bebyggelsen i Tønder var den mindste og yngste, men derimod det forhold, at Ribe-bispens borg i Møgeltønder var større end den fyrsteborg, der blev anlagt til beskyttelse af købstaden Tønder.

Der har antagelig aldrig været en havn ved Møgeltønder, ${ }^{21}$ og derfor skal det »Tundira «, som findes omtalt af Idrisi, søges ved det nuværen- 


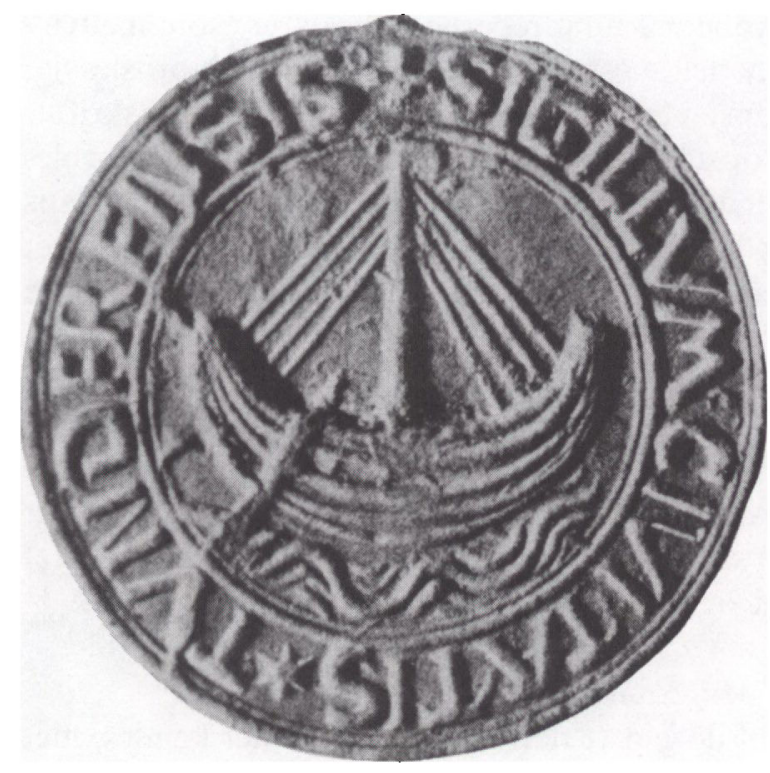

Aldre segl (i forstorret gengivelse) med Tonders byvåben. Skibet markerer, at Tonder var havneby. Omskriften siger:

SIGILLVM

CIVITATIS

TVNDERENSIS.

de Tønder. Ligesom vikingetidens Ribe er fundet på det sted, hvor geesten eller bakkeø-randen nordfra når frem til Ribeå, skal det allerældste Tønder også søges, hvor det faste land nordfra er nærmest Vidåens løb. Skibe, der er sejlet op ad Vidåen, er nemlig her, således som det kendes fra alle andre flod- og åmundinger, søgt så langt op ad vandløbet, som det for hine tiders skibe var muligt. ${ }^{22}$ Det er - om man vil - det geografiske bevis for, at Tønder må have været den betydeligste bebyggelse i sammenligning med Møgeltønder. Tønder ligger nemlig på det sted på geestranden, der ligger længst inde $\mathrm{i}$ landet, hvor skibe - uhindret af eng- og marskarealer kunne finde en ankerplads. Måske stammer selve navnet »Tønder « (i den sønderjyske dialekt: »Tynne«) fra fyrtønder, der er blevet tændt for at vise ankommende skibe, hvor der var en landingsmulighed. ${ }^{23}$

Så tæat ved hinanden ligger de to bebyggelser med oprindeligt samme navn, og alligevel blev der et skel imellem dem. Det var ikke befolkningen, der skabte dette skel, men derimod øvrigheden. Det er betegnende, at det er borgene, der førte til, at der i navngivningen skelnedes mellem de to bebyggelser.

I Møgeltønder kendes fra begyndelsen af 1200-årene en bispegård under Ribe. Den havde vokset sig stor på de øvrige gårdes bekostning og var med sine særjorder blevet anlagt nordøst for landsbyen på et 
sted, hvor det lod sig gøre med voldgrav at befæste en naturlig forhøjning $\mathrm{i}$ terrænet. Måske har det været den gennem 40 år kendte og $\mathrm{i}$ 1043 afdøde biskop Odinkar af Ribe, der efter sin fader, Jarl Toke, havde overtaget en tredjedel af "Sinland " (den tids navn for Sønderjylland), som har befæstet sin magtstilling ned til Vidåen. ${ }^{24}$ Alt dette kan kun blive ved en formodning; men en kendsgerning er det, at Ribe stift $\mathrm{i}$ middelalderen nåede sydpå til Vidåen.

Omtalen af Møgeltønder i 1214 (som nævnt under navneformen "Tønder ( $^{25}$ tyder på, at borgen allerede eksisterede på den tid. I hvert fald var bispens gård i »Tønder«, d.v.s. Møgeltønder, en kendsgerning $\mathrm{i}$ de to breve, der kendes fra 1233 og $1258,{ }^{26}$ da bønderne fik besked på under ledingstog at overholde deres kørselspligt, men først i 1265 bruges benævnelsen Møgeltønderhus. ${ }^{27}$

Der var på den tid - herom senere - en fejde mellem biskoppen af Ribe og Sønderjyllands hertug, og kampene viser med al tydelighed, at Møgeltønderhus har været en torn i øjet på Sønderjyllands hertug. Dette modsætningsforhold har naturligvis på det allernøjeste berørt hertugens by Tønder.

\section{Fra handelsplads til købstad}

Det er som landingssted og ankerplads, at Tønder først findes nævnt, og derfor er det helt naturligt, at et sejlskib indgår $\mathrm{i}$ byens våben. Her som andetsteds $i$ det danske rige må kongemagten have onsket at opkræve told af den handel, der foregik. Næsten naturnødvendigt må der nemlig have fundet en vareudveksling sted mellem ankerpladsen på Vidåens nordlige bred og det mod nord og nordøst derfor liggende opland. Også i Tønder må der f.eks. have været afsætning for det uundværlige salt, som friserne bragte,,$^{28}$ og som i Ribe er bevidnet af navnet Saltgade, men mens Ribes opland var store dele af Nørrejylland, var Tønders mere beskedent. Det omfattede først og fremmest den nordlige del af Sønderjylland, egnen fra syd for Haderslev over Åbenrå og Sønderborg til Flensborg.

Om alt dette kan der naturligvis kun gisnes, selv om sammenligningen med samtidens Ribe er et godt holdepunkt. Kong Valdemars jordebog fra $1231,{ }^{29}$ denne uundværlige kilde til vor viden om kongemagtens indtægter, nævner intet om Tønder, kun om en samlet indtægt på 120 mark af Højer herred og af Lø herred en særdeles beskeden indtægt på 3 foder honning (samt dertil indtægter af Svanstrup og Kumled). Kongens indtægter af Tonder er antagelig indregnet $\mathrm{i}$ den samlede sum for Højer herred ${ }^{30}$, men der findes ikke som f.eks. for 
Haderslevs, Åbenrås og Flensborgs vedkommende ${ }^{31}$ antydninger af, at Tønder udgjorde et særligt bysamfund. Det kunne måske tyde på, at Tønder i 1231 endnu har haft et lignende forhold til øvrigheden som det, Husum havde middelalderen igennem.

At Tønder alligevel, trods det manglende stempel som købstad i form af egen bylovgivning, allerede på jordebogens tid er blevet anset for at have en købstads funktioner, fremgår af, at franciskanerne, gråbrødrene, i 1238 grundede et kloster her. Franciskanerklostre lå altid i byerne, oftest i byer, der var i fremvakst. Helt naturligt fik Lübeck derfor allerede i 1225 - kun to år efter pavens anerkendelse af deres orden - et franciskanerkloster. I det sønderjyske område fandtes sådanne klostre ellers kun i Ribe (grdl. 1232), Slesvig (1234) og Flensborg (1263). Den anden tiggermunkeorden, dominikanernes (sortebrødrenes) havde klostre i Ribe (grdl. 1228), Slesvig (1234) og Haderslev (1254).

Året før klostergrundlæggelsen i Tønder havde hertug Abel overtaget sit herredømme i Sønderjylland, således som hans fader, Valdemar Sejr (død 1241), havde bestemt. Ud fra det bevarede kildemateriale synes Abel (hvis eftermæle for altid er blevet sværtet af mistanken om brodermord) at have været en foretagsom mand. Ligesom hans broder fik øgenavnet Plovpenning for sit ønske om at bøde på de faldende ledingsafgifter med en fast skat, skyldes Abels interesse for byerne ${ }^{32}$ utvivlsomt ønsket om at skaffe sig faste indtægter. Faste indtægter, det var sagen, og det blev som bekendt også hans forsøg på at få skat af friserne, der førte til hans død i 1252.

For et bysamfunds indbyggere var faste skatter og toldafgifter mindre tyngende end alle de fordringer, som en godsherre kunne finde på at udsætte sine fæstebønder for. De citerede breve fra 1233 og $1258^{33}$ er udtryk for nogle af de krav, som Ribe-bispen uden videre kunne stille sine fæstebønder $\mathrm{i}$ Møgeltønder. Købmænd og håndværkere fik derimod som modydelse for skatterne løfte om fyrstemagtens beskyttelse, som oftest synligt udtrykt i form af en borg. Selv om Abels borg i erkendelse af bispeborgens størrelse måtte nøjes med betegnelsen "Lilletønder«, var hertugens magt alligevel stor nok til at kunne yde dette værn, hvis det krævedes. Det var denne kendsgerning, der gjorde det fordelagtigt at høre under hertugen.

Som Sønderjyllands hertug havde Abel utvivlsomt til hensigt at gøre Tønder til en art sønderjysk pendant til Ribe, der på hans tid var Danmarks vigtigste port ud mod vest og sydvest. I sine bestrabelser for at nå dette mål har han taget sit forbillede i Kiel, den holstenske 
by, der lå hans hertugdømme så nær, og til hvis øvrighed han var knyttet med de allernærmeste familiære bånd.

Det tør derfor antages, at det er ham, der ud fra ønsket om at skaffe sig faste indtægter af byen, har sørget for, at der fandt en udvidelse og regulering sted af grundene i Tønder, således at disse, i bebygget stand kaldt »stavne «, kunne pålægges middelalderens almindelige grundskat, den såkaldte »arnegæld«. Byudvidelsen blev så omfattende, at der, ligesom samtidig i Flensborg, i det nye kvarter efter tysk forbillede blev afsat plads til et torv og til en kirke med tilhørende kirkegård. Middelalderen igennem forblev denne kirke dog kun et kapel. Det var indviet til de handlendes og søfarendes særlige helgen, Skt. Nikolaus, altså ganske som i Flensborgs nye kvarter, men i Tønder bevarede den oprindelige kirke, indviet til Skt. Laurentius, sin plads som byens sognekirke.

For yderligere at gøre Tønder attraktiv for købmand og handlende, måtte byen have sin egen stadsret. En sådan betød nemlig, at hertugens bysamfund var blevet en rigtig købstad med egen lovgivning, der var unddraget den lov, der gjaldt for landet som helhed, i det her berørte tilfælde Jyske Lov for det Danske Rige vest for Storebælt.

En skreven stadsret var endnu på den tid i Danmark såvel som i Sønderjylland et yderst sjældent fænomen. I Sønderjylland går Slesvigs stadsret og Åbenrå bys skrå efter alt at dømme tilbage til ca. $1200^{34}$, men det betød ikke, at disse byers særlige lovgivning var kendt uden for en snævrere kreds. Derimod var Lübecks stadsret almindelig kendt, idet den også dannede forbillede for retsvæsenet inden for mange af de nye byer, der som følge af den tyske østkolonisation blev grundlagt ved Østersøen.

Af disse lå Kiel nærmest egnene nord for Ejderen. Denne by var blevet grundlagt af hertug Abels svigerfader, Adolf IV af Holsten, kendt som sejrherren fra Bornhöved i 1227. I 1239 havde Adolf IV opgivet sit verdslige herredømme og havde ladet sig optage som munk i franciskanerordenen. Det blev derfor hans søn og efterfølger, der i 1242 skaffede Kiel den lybske stadsret.

Det er troligt, at det er ad den vej, at Tønder året efter, i 1243, også fik sin stadsret fra Lübeck. I følgeskrivelsen, der er formet som indledning og afslutning til den kopi, ${ }^{35}$ som rådet i Lübeck overlod Tønder, oplyses det, at stadsretten var sendt "på grund af ærbødighed for og kærlighed til Jyllands berømmelige hertug, hr. Abel, og i henhold til lederen af franciskanerordenen i Danmark, broder Reinhards anmodning og til glæde for Tønders borgere« ${ }^{36}$ 


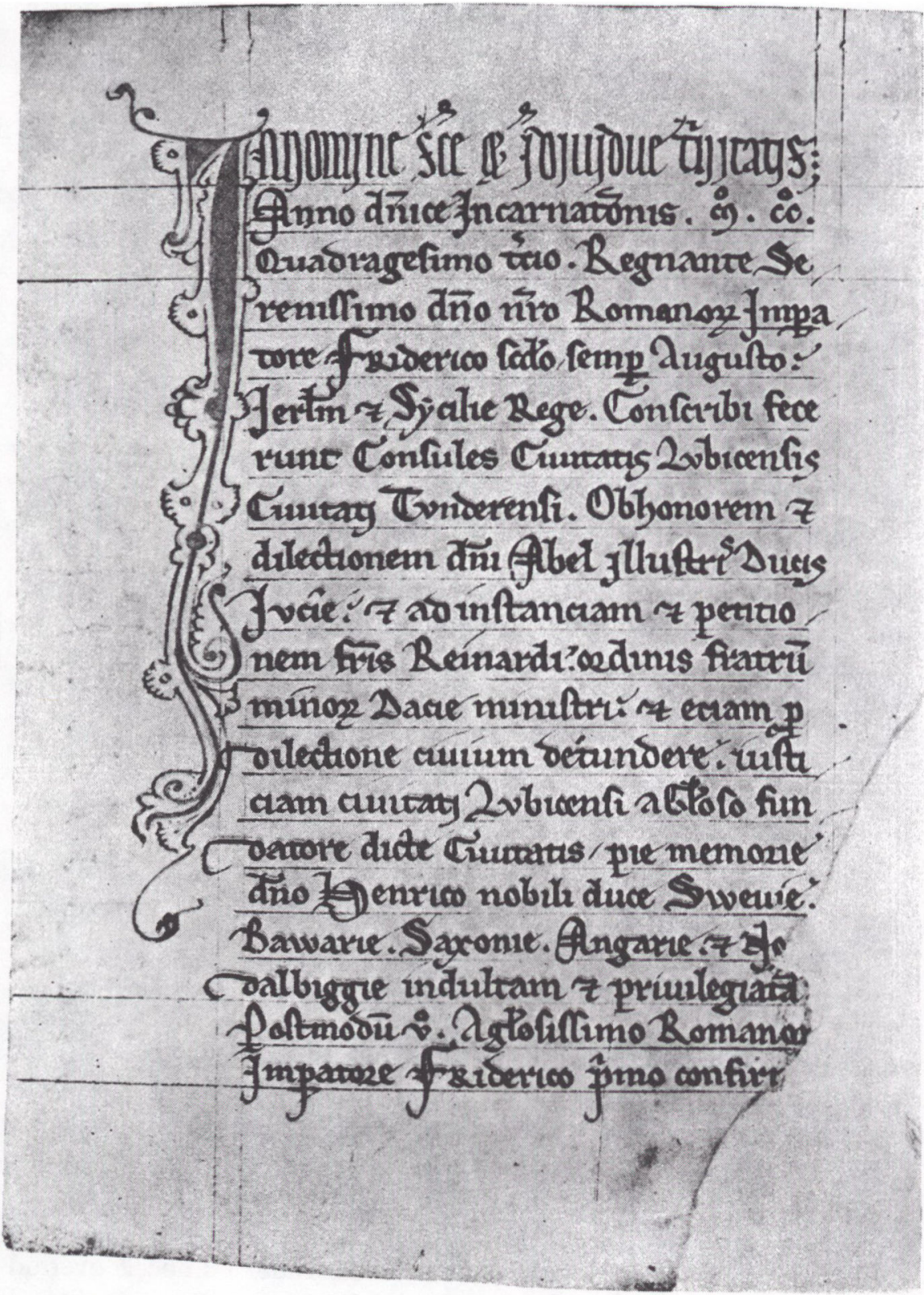

Indledningen til Tonders eksemplar fra 1243 af Lübecks stadsret. 
Franciskanerbroderen Reinhard, der efter navnet at dømme var tysker, var alts̊̊ - som det siges - leder af ordensprovinsen "Dacia" (Danmark, der omfattede klostrene overalt i Norden), men han var samtidig en af hertug Abels rådgivere. Han tilgodeså derfor både sin ordens og sin fyrstes interesse ved at anbefale, at Tønder fik en stadsret. Handelspladsen med franciskanerklosteret var derved blevet en hertugelig købstad, et bysamfund med markedsrettigheder, som hertugen gav sin beskyttelse ved hjælp af sine mænd i borgen, og som han til gengæld modtog faste indtæater af i form af skat og told.

\section{Tonders lybske stadsret $i$ tysk historieopfattelse}

Tønders lybske stadsret er - set såvel fra dansk som fra tysk side - et særsyn. I sammenligning med alle danske - herunder sønderjyske byer er det noget helt enestående, at Tønder har fået en stadsret, der er hentet $i$ udlandet, og blandt alle byer i det tyske rige er Lübeck den eneste by, der har overladt sin stadsret til anvendelse i en by, der ikke lå i Tyskland eller i det slaviske eller baltiske område, der i middelalderen blev koloniseret af tyskerne. Denne kendsgerning er naturligvis ikke forblevet ubemærket.

Ikke mindst har tyske historikere hæftet sig ved dette ganske særlige forhold. De er kommet med udtalelser om, at "tyske kræfter her tidligt har været de førende ${ }^{37}$, at stadsretten "uden tvivl skyldes et tidligt hanseatisk fremstød over Ejderen $\aleph^{38}$, at $» d e n$ formodentligt peger hen på tysk indflydelse ved byens grundlæggelse ( $^{39}$, eller sågar, at hertug Abel muligvis har haft et samarbejde med "en tysk Nikolaikøbmandsgruppe « ${ }^{40}$. Der er således hos de citerede tyske historikere ingen tvivl om, at Tønder tidligt har været udsat for tysk påvirkning.

Denne opfattelse er på det nærmeste blevet en påstand, som der uden videre bygges videre på, og det til trods for, at de nærmere omstændigheder ved Tønders overtagelse af den lybske stadsret blot er de foran nævnte, nemlig dette, at hertug Abels rådgiver, lederen af den danske afdeling af franciskanerordenen, broder Reinhard, havde henvendt sig til Lübeck og opnået et positivt resultat af denne henvendelse.

Eftersom Lübeck var den første by i Nordeuropa, hvor franciskanerne fik et kloster, har broder Reinhard, selv en tysker, naturligvis været fortrolig med forholdene $i$ denne by. Som ledende franciskaner har broder Reinhard antagelig også personligt kendt hertug Abels svigerfader, grev Adolf IV af Holsten, der var blevet hans ordensbroder i 1239. 
En regerende greves farvel til det verdslige liv har naturligvis vakt berettiget opsigt. Hertug Abel har selvsagt også været fuldt vidende om dette skridt, og begge - Abel såvel som Reinhard - har antagelig været bekendt med, at Kiel - grundlagt af grev Adolf - netop havde fået tilladelse til at bruge den lybske stadsret. Da hertugens by Tønder savnede en stadsret, har det derfor været oplagt at foretage en henvendelse til Lübeck, Nordeuropas førende by.

Når der i nutidsformuleringer er blevet talt om »tyske kræfter« eller »tysk indflydelse«, kan der kun være tænkt på den tyskfødte broder Reinhards initiativ. Ud fra en faghistorisk betragtning kan der ikke lægges mere $\mathrm{i}$ disse formuleringer. Har man forestillet sig andet og mere, er man ude i den nationale politiks overdrev. ${ }^{41}$ Helt uden hjemmel i samtidens kildemateriale er påstanden om, at der har været tale om »et hanseatisk fremstød «. Initiativet bliver jo taget af hertug Abels rådgiver, broder Reinhard. Ligeledes er der intetsomhelst belæg for tesen om "tyske Nikolaikøbmænd « ${ }^{42}$ Mere er der sådan set ikke at sige om den sag!

\section{Ekskurs:}

I Tønder gennem Tiderne fra 1943-44 har Stig Iuul behandlet »Træk af retsudviklingen i Tønder« (s. 468).

Han har her givet udtryk for, at overtagelsen af den lybske stadsret $i$ 1243 havde til følge, at tøndringerne også fulgte den i Lübeck gældende uskrevne ret. "Dette førte til, at der i Tidens Løb fandt talrige Henvendelser Sted til Raadet i Lybæk, enten saaledes at man søgte Retsbelæring der, eller saaledes at de af Byraadet i Tønder afsagte Domme ligefrem appelleredes til Lybæk. Byraadet i Lybæk blev saaledes Appeldomstol i Forhold til Tønder paa samme Maade som det var det for adskillige holstenske Byer, Rostock, Stralsund, Wismar, Reval, ja endog for de hanseatiske Købmænd i Bergen «.

Jeg har selv i min Plattysk i Sønderjylland (s. 45) uden videre fulgt vor højt ansete retshistoriker $\mathrm{i}$ hans fremstilling, men må nu - bl.a. efter drøftelse med middelalderhistorikeren Thomas Riis - tage afstand fra denne opfattelse.

Stig Iuul henviser i sin fremstilling til registeret i A. L. J. Michelsen: Der ehemalige Oberhof zu Lübeck und seine Rechtssprüche (1839), men intetsteds $i$ denne bog gives der eksempler fra Tønder. Ud over Burg på Fehmarn opregnes der her syv holstenske byer (bl.a. Kiel) og foruden Reval (der optræder flest gange) og det hanseatiske kontor $\mathrm{i}$ Bergen endnu sytten tyske (østtyske) byer.

Når Tønder ikke nævnes, må det ganske simpelt skyldes, at denne bys øverste retsinstans repræsenteredes af den sønderjyske hertug. Der forekom med andre ord ingen henvendelser til Lübeck fra Tønder!

Stadsretten fra Lübeck var en gave, som tøndringerne kunne gøre 
brug af; men den betød ingen fremtidig afhængighed af retspraksis i Lübeck.

\section{Tonder og Mogeltonder $i$ hver sin lejr}

Altimens købstadboerne i Tønder efter 1243 kunne glæde sig over at have fået deres egen, dengang helt moderne stadsret, der gav dem en andel $\mathrm{i}$ deres bys styrelse, vidner som nævnt de to, i vor tid kendte breve fra Bibe-bispen i $1233 \mathrm{og} 1258^{43} \mathrm{om}$, at han som enhver anden godsherre var ivrig for at indskærpe sine undergivne deres forpligtelser over for herskabet.

I det første af de to breve minder biskoppen sine undersåtter om pligten til at levere fødevarer i tilfælde af, at der bliver udbudt leding "med skibe og sømænd eller med heste uden for Jylland «, samt at den havre, der nævnes som skatterne "stud « og »(biskops)gave«, for egen regning bliver afleveret $\mathrm{i}$ Lustrup, bispens gård $\mathrm{i}$ nærheden af Ribe. I det andet af de to breve kræves det, at fæstebønderne årligt hver for sig skulle bringe et læs brænde og et læs hø til bispegården $\mathrm{i}$ Lustrup, og under ledingstog skulle der af hver 5 ottinger fastegods afstås en vogn til biskoppens brug.

Netop på den tid var ledingsforpligtelserne blevet bitter alvor, idet ærkebiskop Jacob Erlandsen i 1256 havde bandlyst kong Christoffer I. Under den kirkekamp, der blev en følge af bandlysningen, valgte Ribe-bispen at holde med kongen, mens Sønderjyllands hertug, Abels søn Erik I, fulgt af Slesvigs biskop, støttede ærkebiskoppen. Dermed var signalet givet til en kamp også på Tønder-egnen, og i 1265 lykkedes det Erik Abelsøn at ødelægge Ribe-bispens faste hus i Møgeltønder. ${ }^{44}$ Nogen tid efter blev de to parter dog forligte, og alt vidner om, at borgen i Møgeltønder fortsat hørte under Ribe.

Alligevel er der grund til at hæfte sig ved denne kamp. Den er nemlig det ældst kendte vidnesbyrd om, at beboerne i Tønder og Møgeltønder under opgøret mellem hertugen og Ribe-bispen hørte hjemme i hver sin lejr. Men det skulle ikke forblive det eneste kendte eksempel herpå. Tværtimod var det middelalderen igennem regelen, at de to byer af samme navn hørte til hver sin lejr.

I kampene mellem Erik, Abel og Christoffer og mellem de to sidstes efterkommere kom Tønder atter og atter i brændpunktet. I 1248 fratog Erik Plovpenning sin broder Abel Tønderhus og Tønder købstad. I 1271 indtog Erik Klipping Tønderhus og lod borgen sløjfe. Året efter var kong Erik atter $\mathrm{i}$ Tønder og sidste gang var i 1285, året før han blev myrdet i Finderup lade. 
Kampene mellem de to grene af den gamle kongeslægt var ophørt, da Gerhard III af Holsten-Rendsburg (grev Gert, »den kullede greve«) i 1325 havde gjort sig til herre over Sønderjylland og det danske rige vest for Storebælt. Efter hans voldsomme død i 1340 var Tønder med borg og fogedi pantsat til grevens sønner, ${ }^{45}$ indtil det i 1344 lykkedes Sønderjyllands hertug, Valdemar V, at indløse pantet. ${ }^{46}$ Det betød, at hertugen og hans søn, de sidste af Abels slægt (der uddøde 1375), kun havde den nordlige del af Sønderjylland at regere over, nemlig landet nord for linjen Tønder-Flensborg, med andre ord den senere »Clausenlinje«, idet Kær herred hørte under fogediet Læk $^{47}$.

Tønder var dermed igen under den sønderjyske hertug, men det kom kun til at vare i ti år, fordi Danmarks konge, Valdemar Atterdag, i 1354 under et hærtog mod Nordfrisland satte sig i besiddelse af Tønderhus. Hertugen fik imidlertid hjælp af de holstenske grever, hvem det i 1357 lykkedes at fravriste kongen Tønder, ${ }^{48}$ men først under de påfølgende fredsforhandlinger et par år senere fik Sønderjyllands hertug atter herredømmet over Tønder.

Under de mange års omskiftelser nævnes Ribe-bispens gård i Møgeltønder kun en enkelt gang, nemlig i 1338, ${ }^{49}$ og når hertug Valdemar V af Sønderjylland derfor i 1361 overlod alle sine og hertugdømmets rettigheder i Møgeltønder sogn til Ribe bispestol, ${ }^{50} \mathrm{er}$ der antagelig tale om, at hertugen dermed godkendte, at alt skulle være som før. Ligesom Tønder var i hertugens besiddelse, skulle Møgeltønder også fremover forblive i Ribe-bispens eje, og det skulle være slut med de forsøg, der $\mathrm{i}$ årenes løb var gjort fra de sønderjyske hertugers side på at få herredømmet over Møgeltønder.

Man går næppe fejl ved at antage, at hertugens anerkendelse af Ribe bispestols rettigheder i Møgeltønder skal ses som en følge af den store landefred, som Valdemar Atterdag fik vedtaget på danehoffet $i$ Kalundborg i 1360. Det var her blevet besluttet, at hertug Valdemar $\mathrm{V}$ og hans søn "frit og fordelagtigt skulle nyde alle deres love og rettigheder, som nogen hertug af Jylland frit og mest fordelagtigt har kunnet det fra arilds tid." Men til gengxld måtte de samme hertuger "på deres tro love" at holde landefreden i overensstemmelse med gammel skik og brug. ${ }^{51}$

Netop som Valdemar Atterdag i 1375 skulle til at overtage dødsboet efter de sønderjyske hertuger af Abels slægt, døde han selv, og de holstenske grever var ikke sene til at udnytte den svækkelse af den danske rigsmagt, som var den umiddelbare følge af kongens død. De besatte hurtigt hele Sønderjylland, og i august 1386 besluttede dronning 
Margrethe af taktiske grunde at anerkende deres herredømme over grænselandet, men på betingelse af, at de tog Sønderjylland som et len af Danmark. ${ }^{52}$

For Tønder betød dette, at byen i hvert fald fra 1377 var under uafbrudt holstensk styre. Det var derfor kun en naturlig følge af dronning Margrethes anerkendelse, at den holstenske greve straks i september 1386 bekræftede Tønders privilegier. ${ }^{53}$

I den langvarige krig om herredømmet over Sønderjylland, der førtes i årene fra 1409/10 til 1431/35, var først og fremmest Flensborg brændpunktet, men der var også jævnligt kampe om Tønder, der dog i hele perioden forblev på holstenske hænder. Næppe var krigen overstået, før sejrherren, Adolf VIII, i sin egenskab af hertug af Sønderjylland (eller som man nu sagde: af Slesvig) og greve af Holsten i 1436 bekræftede Tønders privilegier. Bemærkelsesværdigt er det, at han da benyttede lejligheden til at takke »byens indbyggere for deres trofasthed og velgerning imod ham og hans forfædre ${ }^{54}$ Det er med andre ord et udtryk for, at middelalderens mennesker også kunne tage et politisk standpunkt.

I de følgende år fulgte Tønder grænselandets almindelige udvikling. Det betød, at Tønder efter det berømmelige møde i Ribe fik Danmarks konger af det oldenburgske hus som deres hertuger, men det betød også, at Tønder, hver gang der eksisterede en sidelinje af dette kongehus, hørte under sidelinjen. Det gjaldt 1490-1523, da den senere kong Frederik I endnu kun var gottorpsk hertug, det gjaldt endvidere, da Hans den Fldre 1544-80 havde sit lille haderslevske hertugdømme, der også omfattede Tønder, og det gjaldt for årene 1580-1720, da Tønder var en del af det gottorpske hertugdømme, "Slesvig-HolstenGottorp«.

I løbet af denne lange udvikling var skellet mellem Tønder og Møgeltønder blevet stedse skarpere. I 1407 var det lykkedes dronning Margrethe at erhverve Trøjborg gods, og dette skænkede hun omgående til Ribe bispestol. Derved skete der en kendelig udvidelse af det bispegods, der havde Møgeltønderhus som kærnepunkt, og da denne erhvervelse ikke blev omstødt ved fredsslutningen i 1435, men tværtimod udvidet med Vesterland-Føhr og List på nordspidsen af Sild, ${ }^{55}$ er der næppe tvivl om, at begejstringen for Ribe bispestol i Tønder har kunnet ligge på et meget lille sted.

Biskoppen af Ribe var i middelalderen som dansk stormand medlem af Danmarks rigsråd, og hans styre af de områder, der siden har fået betegnelsen »De kongerigske« eller »nørrejyske Enklaver«, fulgte 


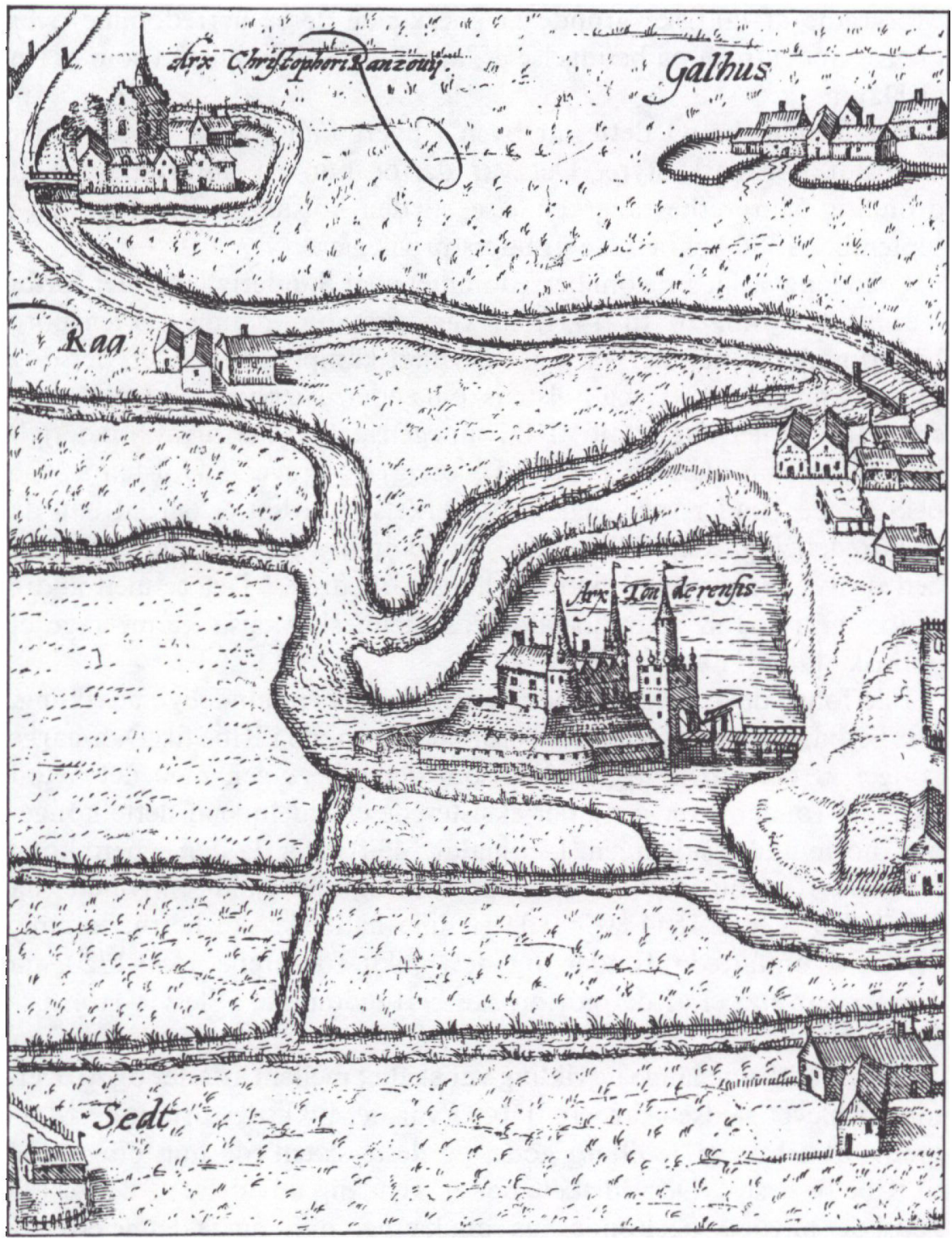

Mogeltonderhus og Tonderhus efter stik i Braunius og Hogenbergs Städtebuch fra 1588. Når Mageltonderhus er mindre pd dette stik, skyldes det et forseg pd at vise afstanden fra Tonder. 
derfor den lovgivning, der gjaldt i kongeriget Danmark, d.v.s., at Møgeltønder og det dertil hørende bispegods ikke hørte til hertugdømmet Slesvig. Denne administrative ordning gjaldt helt til 1864 .

I kirkelig henseende hørte Tønder ligesom Møgeltønder (og Højer) til Ribe stift, men i det lange tidsrum, da holstenerne havde herredømmet, indtog det plattyske sprog efterhånden førstepladsen i byen som administrationens sprog. Det var måske noget, der allerede var begyndt i 1325. I hvert fald var det en kendsgerning efter Adolf VIIIs sejr $i$ 1435. På den tid havde det ført til, at byens ledende borgerskab gjorde brug af dette sprog, så snart noget »højere« og "fornemmere« skulle udtrykkes, noget som den hjemlige dansk-sønderjyske dialekt ikke egnede sig til. Det betød, at det plattyske sprog også helt naturligt vandt indpas i kirkens forkyndelse. Det blev derfor nødvendigt, at Tønder fik tysksprogede præster. ${ }^{56}$

Den første, vi kender, er Johann Meyndorp, født i Hamburg i 1448 og forfatter til en håndskreven postille på plattysk. Den sidste før reformationen er Johann Overscherer. Han var fra Gottorp og fik i året 1500 sin kollats af biskop Iver Munk. Ribe-bispen har tilsyneladende fundet det $\mathrm{i}$ orden, at købstaden Tønder under Ribe stift, men beliggende $\mathrm{i}$ hertugdømmet Slesvig (der indtil 1840 havde tysk øvrighedssprog), fik en præst sydfra.

Noget sådant var naturligvis helt utænkeligt i nabosognet Møgeltønder, der både i verdslig og gejstlig henseende var en del af kongeriget Danmark. I Højer derimod blæste der andre vinde. Ved år 1500 havde Højer overtaget Tønders rolle som havneby som følge af skibenes større dybgående. Herfra kendes i 1485 et klagebrev til den verdslige øvrighed over, at den daværende biskop af Ribe havde krævet "gæsteri« i Højer. ${ }^{57}$ Et sådant krav, der føltes som en art ekstraskat, havde Ribebisperne aldrig tidligere fremsat, og afvisningen tyder på, at sognefolket i Højer ønskede at have så lidt som muligt at gøre med stiftsstaden Ribe. Det er bemærkelsesværdigt, at den kulturelle udvikling allerede så tidligt peger sydpå i Højer, ganske svarende til den, der kendes fra købstaden Tønder. Også i Højer ønskede man at markere skellet til Møgeltønder.

Under reformationen, der i Sønderjylland var blevet indledt, efter at den senere Christian III i 1525 var blevet hertug af Haderslev og Tørning, er det helt tydeligt, at Tønders borgere ønskede at følge den udvikling, der fandt sted i Slesvig stift. Til trods for Iver Munks indsigelse over for hertug Christian i Haderslev fik Tønder ligesom de 
andre sønderjyske købstæder en evangelisk præst allerede i 1526. Han hed Johann Decker og blev hentet direkte fra Wittenberg. ${ }^{58}$.

Det er helt tydeligt, at tøndringerne ønskede at benytte kirkeforandringen til at løsgøre sig fra Ribe, og hertil fandt de beredvillig støtte hos den verdslige magt, hvem det syntes unaturligt, at det vestlige Nordslesvig mellem Vidåen og Kongeåen hørte under et kongerigsk stift.

Efter Johann Deckers død i 1540 var det Slesvigs biskop, Gottschalk Ahlefeldt, der bekræftede byrådets valg af hans efterfølger og lod ham indsætte i embedet. Kongerigets biskopper var blevet fjernet i 1536, og Gottschalk Ahlefeldt, der fra den gamle kirkes tid uanfægtet fortsatte den administrative del af sin bispegerning i Slesvig, fordi han straks i 1533 havde anerkendt Christian III som konge, har nok anset sig selv for den rette til at bekræfte det stedfundne præstevalg. ${ }^{59}$ Ribe havde jo efter 1536 fået en evangelisk superintendent (lutheranernes navn for en biskop).

I årene 1544 til 1580 hørte Tønder som nævnt under hertug Hans den Eldre af Haderslev, og han ønskede en egen fyrstekirke for sit lille hertugdømme, helt uafhængig af Ribe stift. I 1550 fik Tønder by og amt derfor en egen superintendent ${ }^{60}$, og dette embede, og et tilsvarende for Haderslev-Tørning fastholdt han indtil sin død. En voldgiftsdom i 1578 havde endda givet ham medhold, men efter 1580 genskabtes de tidligere administrative forhold for kirkens vedkommende, dog med den undtagelse, at Tønder by og en række sogne deromkring (bl.a. Højer, Ubjerg, Abild, Brede etc.) kun med hensyn til kirkeregnskaberne var underlagt et tilsyn fra Ribe. ${ }^{61}$ Reformationen var derfor med til at uddybe skellet mellem Tønder og Møgeltønder.

Skellet mellem kongerigsk og hertugelig blev ikke slettet I løbet af den gottorpske tid fra 1580 til 1720 skærpedes forholdet mellem Tønder/Højer og Møgeltønder i takt med den almindelige politiske holdning.

Dagligdagens sprog var $\mathrm{i}$ de to gottorpske byer fortsat lige så dansk som i Møgeltønder. Det ses bl.a. af, at den gottorpske generalprovst Jacob Fabricius (den ældre) i sine erindringer oplyser ${ }^{62}$, at han ikke kunne ét ord på tysk, da han som barn kom fra Tønder til Rendsburg, og at han nogle år senere, da han som stor dreng vendte tilbage til Tønder og i mellemtiden i Rendsburg havde glemt sit danske sprog, spottende blev kaldt »den tyske Jacob« af sine kammerater. 


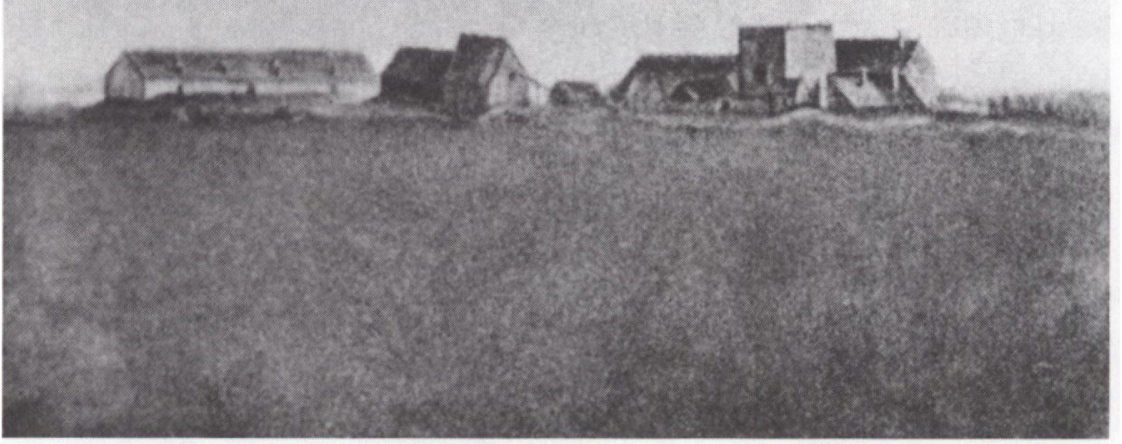

Mogeltonderhus ca. 1650. Efter maleri på herregdrden Skokloster ved Uppsala. fort dertil som krigsbytte.

Det var derfor ikke folkesproget, der skilte, men i alle fire nordslesvigske købstæder var det tyske sprog både den verdslige og den gejstlige øvrigheds sprog. I reformationens første årtier var det endnu det plattyske sprog, der indtog pladsen som det whøjere« sprog, og det er karakteristisk for denne sprogligt-kulturelle situation, at Tønders borgmester og råd i 1631 protesterede imod, at deres nyansatte sognepræst efter den tids skik var begyndt at prædike på højtysk, Lutherbibelens sprog. "Det plattyske sprog - die sächsische Sprache - var mere forståeligt for den enfoldige menighed «, klagede bystyrets mænd, og præsten fulgte henstillingen. ${ }^{63}$ Overgangen til højtysk $\mathrm{i}$ Tønders bykirke skete først i 1652, da Stephan Kenckel blev Tønders provst og førstepræst.

I hertugdømmets nordslesvigske landsogne var kirkens og skolens sprog ganske vist dansk, men den verdslige øvrighed benyttede sig af tysk. Unge fra landet, børn af den sønderjyske bonde-overklasse, måtte derfor søge til byernes »tyske skrive- og regneskoler«, dersom de ønskede en fremtid inden for administrationen, f.eks. som fogeder eller skrivere. Kendte eksempler herpå fra Tønders nærmeste omegn er 
medlemmer af herredsfogedslægten fra Hajstrup i Bylderup sogn, den navnkundige Nis Hinrichsens efterkommere. ${ }^{64}$ Drengene herfra fik en videregående uddannelse i de nærliggende købstæder, Tønder og Flensborg, $o g$ i visse tilfælde fortsattes deres uddannelse i Lübeck og Lüneburg.

Som det sprog, den verdslige øvrighed benyttede sig af også ude i landsognene, blev tysk derfor brugt ved udstedelser af tingsvidner og ved indførsler $\mathrm{i}$ tingbøgerne og det på trods af befolkningens dansksønderjyske dagligsprog. Ligesom man i 1631 i Tønder havde klaget over en præst, der havde benyttet lutherdommens mere uforståelige højtyske sprog i sine prædikener, skal det også ses som et karakteristisk udtryk for den sproglige situation, at man i Slogs herred holdt fast ved plattysk som øvrighedssprog, længe efter at det andetsteds var blevet afskaffet, nemlig helt til $1683 .^{65}$ For de dansk-sønderjyske bønder var det nemmere at forstå end højtysk, og Slogs herred bliver derfor antagelig det sted $\mathrm{i}$ hele verden, hvor plattysk har holdt sig længst som kultursprog!

I Møgeltønder og de øvrige enklavesogne var alt dette totalt anderledes. Her fulgte udviklingen de samme retningslinjer, som gjaldt i Ribe stifts og stiftamts vestjyske sogne nord for Kongeåen. Det medførte, at der generation efter generation blev vedligeholdt en forståelse for, at det ikke var ligegyldigt, om man var kongerigsk eller hertugeligslesvigsk undersåt. Det er ud fra dette, at der kan tales om, at et "åndeligt klima« skilte beboerne i Møgeltønder fra dem, der var bosatte i Tønder og Højer.

Særligt skarpt blev dette skel i de år, da gottorperstyret søgte at gå enegang i forhold til den danske kongemagt og ovenikøbet under 1600årenes store krige prøvede at befæste sin stilling ved at knytte sig nært til Sverige, den danske kongemagts hovedfjende. Kronen på dette værk blev den danske konges aftvungne anerkendelse i 1658 af, at den gottorpske hertug var en uafhængig og suveræn fyrste i sit landområde. Der var herefter tale om en stat »Slesvig-Holsten-Gottorp«.

Dette blev af afgørende betydning, da den danske kongemagt to gange (1675-79 og 1684-89) forsøgte at gøre en ende på den dynastiske strid ved at foretage en militær besættelse af de gottorpske dele af Slesvig. Fra den tid forekommer der klare tilkendegivelser om en gottorpsk stats- og fyrstetroskab, først og fremmest hos embedsmændene, der følte sig bundet af deres troskabsed til hertugen. I Tønder var det provst Stephan Kenckel, der ledede modstanden mod den kongelige øvrighed, der fulgte med besættelseshæren. I 1677 nægtede 
62 fremmødte gejstlige under ledelse af provsterne Troels Arnkiel i Åbenrå og Stephan Kenckel i Tønder at aflægge troskabsed til Danmarks konge, og sagen blev derefter opsat indtil videre. Under den nye kongelige besættelse blev der i stedet rejst et krav om, at alle embedsmænd skulle indsende deres kalds- og ansættelsesbreve til kongelig stadfæstelse, og i 1685 valgte Stephan Kenckel da i modsætning til sin embedsbroder i Åbenrå at rette sig efter dette påbud.66

Disse stridigheder er tidligere blevet opfattet som udtryk for en national tilkendegivelse ${ }^{67} \mathrm{i}$ slægt med dem, der forekommer efter den nationale vakkelse i 1830-40rne, men ud fra den tids tankegang var der tale om det undersåtlige troskabsforhold. I det kongelige Flensborg kan hine tiders »danske øvrighed heller ikke tåle en bedømmelse ud fra en senere tids kriterier.

Under den store nordiske krig (1700-1720) lykkedes det omsider den danske kongemagt at nå sit mål. Hele hertugdømmet Slesvig, hele det sønderjyske område, kom ved inkorporationen i 1720 under kongeligt styre; men det betød ikke, at landsdelen blev indlemmet $\mathrm{i}$ kongeriget Danmark. Det særlige hertugdømme og dets administration bestod også fremover, og der var også efter 1720 tale om en nøje tilknytning til Holsten (kongens andel af Holsten) og efter mageskiftetraktatens ikrafttrædelse i 1773 til hele Holsten.

De tidligere gottorpske sympatier synes at være svundet bort ret hurtigt efter 1720 . Hertil har antagelig bidraget, at den gottorpske fyrstestat i årene efter 1708-09 kom under den berygtede baron Görtz's misregimente. En lang række klagepunkter findes opregnet mod hans styre. Ikke mindst vejede det tungt, at han fik pålagt undersåtterne en særlig skat i forbindelse med den såkaldte Lüneburgske Saltoktroi. ${ }^{68}$ Det var noget, der skabte modvilje og bitterhed selv hos de allerjævneste af gottorperhertugens undersåtter. Desuden har det nok været af den allerstørste betydning for, at de tidligere gottorpske byer og egne så hurtigt fandt sig til rette under det nye kongelige styre, at der intet ændredes i de hidtil bestående administrative og sprogligt-kulturelle forhold. Nok var der nu nye kongelige embedsmænd (blandt dem også nogle af de tidligere hertugelig-gottorpske), men det administrative mønster ændredes ikke.

Alt dette betød, at der også efter 1720 gik et klart skel mellem det kongerigske Møgeltønder og Tønder/Højer, hvor Danmarks konge nu var sin egen hertug af Slesvig. Med andre ord: begrebet »det hertugelige « eksisterede fortsat. De love, der blev udstedt af Danske Kancelli i København gjaldt $\mathrm{i}$ kongerigerne Danmark og Norge og dermed også 
i Møgeltønder og for de øvrige enklaveundersåtter, men ikke i hertugdømmerne Slesvig og Holsten. Her var Tyske Kancelli i København øverste administrative instans. Ingen skulle være i tvivl om opdelingen af den gamle "helstat « efter en linje fra Kolding fjord til Kongeåen. Der var helt klart i lovgivningen på alle områder tale om et nord og et syd for denne grænse, og for de kongerigske enklaver betød det uden vaklen et tilhørsforhold til kongeriget.

For befolkningen på begge sider af skellet var denne forskel så meget mere iøjnefaldende, fordi enklaverne var et udpræget godsområde med centrum i Schackenborg (der havde afløst det gamle Møgeltønderhus) og Trøjborg. Her som i andre kongerigske godsdistrikter var bondeufriheden almindelig, og Møgeltønders historie er derfor helt siden middelalderen præget af stridigheder mellem godsherskab og fæstebønder. ${ }^{69}$

Det er disse forhold, der forklarer, at der i den sønderjyske befolkning var en så udpræget tilfredshed med at være slesvigsk undersåt, og at sympatien for det hertugelige var så udbredt. I hertugdømmet var hoveriet tidligt blevet afløst af en fast pengeafgift, og her gjaldt lovgivningen om stavnsbåndet ikke. Det stod også bønderne frit at handle med deres produkter på markeder eller i købstæderne. Alt dette var åbenbare fordele ved at være bosat $\mathrm{i}$ hertugdømmet. Og i en købstad som Tønder behøvede man blot at foretage en sammenligning med tilstandene $\mathrm{i}$ Ribe for at blive klar over de restriktive regler, hvorefter købmandskab blev drevet $i$ en kongerigsk by. ${ }^{70}$

Tilfredsheden med de bestående tilstande kom tydeligt til orde, da den europæiske uro i tiden mellem 1789 og 1815 også rystede det dansk-norsk-slesvig-holstenske monarki. Begrebet "Patria«, "Vaterland «, "Fædreland " var nøje knyttet til den gamle helstat, og det er først efter statsbankerotten og tabet af Norge, at nye tanker om en folkelig samhørighed voksede frem.

Mange gamle slesvigere har i årene forud for 1848 udtalt frygt for, at den danske vækkelse i Nordslesvig (med tyngdepunktet på Haderslevegnen) kunne føre til en indlemmelse af hertugdømmet $\mathrm{i}$ kongeriget. Kendt er, hvorledes selv en Peter Hiort Lorenzen måtte arbejde sig ud af sådanne stemninger. ${ }^{71}$ Væsentligt for den nationale udvikling i Tønder er nok - som foran påpeget af Claus Eskildsen ${ }^{72}$ - at man ikke her som i Åbenrå fik en dansksindet foregangsmand, der kunne modvirke en sådan gennem århundreder nedarvet forestilling. Udviklingen i kongeriget Danmark efter grundloven i 1849 kom jo netop til at vise, at den moderne tids udvikling ofte fandt først sted nord for Kongeåen. 
I Tønder forblev desuagtet det ledende borgerskab fast knyttet til det »hertugelige«, og da hertugen af Augustenborg drog politisk fordel af denne stemning, sluttede tøndringerne sig til slesvig-holstenismen på trods af de bindinger, som de fleste af dem havde til deres dansksønderjyske folkesprog.

Som det efter overgangsperioden 1864 til 1871 gik de fleste slesvigholstenere, fandt også tøndringerne sig til rette under det nye Tyske Rige. De var blevet tyskere! I Møgeltønder var det stik modsatte tilfældet. Her var man dansk.

Stemmeafgivningen ved folkeafstemningen den 10 . februar 1920 viser klart skellet mellem de to byer af samme navn.

Den herværende fremstilling har haft til formål at påvise, at det høje stemmetal i Tønder og Højer i 1920 ikke skyldtes beboernes dybe og inderlige tilegnelse af den tyske kultur (endsige det tyske sprog), men først og fremmest det historisk betingede modsætningsforhold til »det kongerigske«, repræsenteret af Møgeltønder og Ribe, og dermed til begrebet »det danske«.

\section{NOTER}

1. Redaktør Aksel Lassen har i Valg mellem dansk og tysk, 1976, s. 171, beregnet den tyske andel af de bosiddende valgere ud fra en gennemsnitlig stemmeprocent på 92 og kommer derved til det resultat, at kun en stemmeprocent over 46 betyder et egentligt tysk flertal. En sådan beregning viser, at det tyske flertal i Åbenrå og Sønderborg ikke holdes og knap og nap i Tinglev. Herefter er der kun et klart tysk flertal i Tønder-hjørnet.

2. Citeret efter Valg mellem dansk og tysk, s. 204.

3. H. V. Clausen: Før Afgørelsen, s. 34f.

4. Troels Fink: Da Sønderjylland blev delt 1918-1920, 1978-79; Harald Jørgensen: Genforeningens statspolitiske baggrund, 1970.

5. Ernst Siegfried Hansen: Kurier der Heimat, 1955, s. 37 ff.

6. Se: Sønderjysk Månedsskrift, 1956, s. 155-158, 174.

7. Det er på denne baggrund, at man skal bedømme afvisningen af den provisoriske regering i det meste af Nordslesvig. Sognefogeden i Bjolderup vestersogn klagede i 1848 over sine sogneboere: »Hvor jeg kommer, er Folket lidt vranten. "Er du Provisorisk? Vi har ikke med Tyskerne at bestille. Den provisoriske Regjering kjender vi ikke; den har os ikke noget at befale osv. u“ (H. V. Gregersen: Fra den nationale Vækkelse i landsognene omkring Åbenrå, Sønderjyske Árbøger, 1951, s. 161-201). Se også: H. V. Gregersen: Af Slogs herreds nationale historie indtil 1864 (Sønderjyske Årbøger, 1953, s. 61-81).

8. Denne iagttagelse bygger på en personlig oplevelse under et besøg på Toldsted ved Hærvejen, hvor den hjemmetyske bonde i sin tid gjorde mig opmærksom på ordene "Schleswig, Holstein etc« på ejendomspapirerne. - Se i øvrigt: »Den nationalpoliti- 
ske udvikling i grænseegnene i historisk belysning", nogle foredragsudtog bragt $i$ Sønderjysk Månedsskrift 1966, s. 381-386.

9. P. Lauridsen: Da Sønderjylland vaagnede, II, 1911, s. 3. - Om dette varks tilblivelseshistorie, se: Kampen for Laurids Skaus eftermæle. Et bidrag til den sonderjyske historieskrivnings historie (Sønderjyske Årbøger, 1969, s. 148-179, spec. s. 166ff.).

10. Ludwig Andresen: Geschichtliche Voraussetzungen, Entwicklung und Durchbruch des Nationalbewusstseins des Heimdeutschtums im "Schiefen Viereck« in Nordschleswig (Deutsche Hefte für Volksforschung, 3.-4. Jahrgang, 1933-34, s. 208-220, 41-58); endvidere sm. i udtog: Der Schleswig-Holsteiner, 1934, s. 233-240; Deutsches Archiv für Landes- und Volksforschung, I, 1937, s. 71-94.

11. Troels Fink: Gottorperstyret som forudsætning for hjemmetyskheden i Nordslesvig (Fortid og Nutid, XV, 1943-44, s. 107-119). Som eneste eksempel nævner Ludwig Andresen (efter: C. Petersen: Nicolaus Falck und die Entstehung des schleswigholsteinischen Gedankens (Jahrbücher der Schleswig-Holsteinischen UniversitätsGesellschaft, 1926, s. 16)), at gamle folk i Emmerlev i Niels Falcks barndom, d.v.s. for år 1800, endnu kunne huske begivenhederne i 1762, da Danmark var truet af Ruslands gottorpske zar, Peter III, men det siger jo ret beset intet om et positivt gottorpsk sindelag.

12. Der kendes mange eksempler herpå, f.eks. Schweiz's befolkning i forhold til tyskere, franskmænd og italienere og forskellen mellem hollændere og flamlændere.

13. Den gav sig også udtryk $\mathrm{i}$ de mange tilrejsende, der kom sydfra. Nok var der flest tilrejsende nordfra $i$ 1920, i alt 16.638, mod 11.069 sydfra, men i alle købstæder og flakker - alene bortset fra Haderslev - var de tilrejsende sydfra i overtal. Det var fortrinsvis børn, født i tyske embedsmandsfamilier, mens disse som unge tjente deres levebrød i det tyske riges nordligste udkant, der nu som voksne ønskede at stemme for tyskheden. Af den bosiddende befolkning i Sønderborg blev der kun afgivet 2 - to - flere tyske stemmer end danske i 1920! Se. Aksel Lassen: Valg mellem tysk og dansk, 1976, s. 167-168. De danske tilrejsende var som regel fra landdistrikterne, ofte gårdmandssønner, der ikke ønskede at blive indkaldt til tysk soldatertjeneste og derfor var flyttet nordpå.

14. Herom f.eks.: H. V.Gregersen: 100 års læreruddannelse ved seminariet i Haderslev, 1884 - 12. maj - 1984 (Festskriftet Haderslev Statsseminarium, 1984).

15. Claus Eskildsen: Tønder 1243-1943, 1943, s. $155 \mathrm{ff}$.

16. Jvf. note 11 .

17. Namn och Bygd, 1931, s. 33; Die Heimat, 1934, s. 288 f.

18. Et kendt eksempel er bebyggelserne ved Sliens inderste vig, hvor Hedeby og Slesvig bruges om bosættelsen både syd og nord for Slien og med det resultat, at den tyske navneform Slesvig sejrer.

19. DD/DRB, 1. rk., V, nr. 45 (hvortil registeret har "Tønder« som opslagsord); jvf. Ludwig Andresen i Zeitschrift d. Ges. f. Schl.-Holst. Geschichte 1936, s. 468; Sønderjyske Stednavne, Tillæg, s. 176.

20. Ludwig Andresen: Geschichte der Stadt Tondern, 1939, s. 5-6 (med udgangspunkt i guldhornefundet ved Gallehus); Tønder gennem Tiderne, 1943, s. 33-36 (Vilhelm Lorenzen).

21. Møgeltønder, Slotsby og Bondeby, udg. 1985 af Fredningsstyrelsen og Tønder Kommune, s. 9-10 (Peter Kr. Iversen).

22. Kendte eksempler er Hamburgs, Bremens, Londons beliggenhed ved deres respektive floder. 
23. Sønderjyske Stednavne, III (Tønder Amt), 1 f., 667; I (Tillæg), s. 169.

24. H. V. Gregersen: Det middelalderlige Kollegiatkapitel i Haderslev og dets embedsområde, Barved syssels provsti (Sønderjyske Årbøger 1985, s. 15-34, spec. s. 15-16). Adam af Bremen har fejlagtigt »Winland«. Se også: J. Kinch: Ribe Bys Historie og Beskrivelse, I, 1869, s. 50-76.

25. Jvf. note 19.

26. DD/DRB, 1. rk., VI, nr. 168; 2. rk., I, nr. 257. Jvf. J. Kinch, anf. vark, s. 50-51.

27. Jvf. note 24 , spec. s. 19 .

28. Jvf. f.eks.: H. V. Gregersen: Den Lüneburgske Saltokroi. Et bidrag til salthandelens historie i hertugdømmet Slesvig, 1962, s. 16-29.

29. Kong Valdemars Jordebog, udg. Svend Aakjar, 1926-45.

30. Det senere Tønder herred må vare udskilt af Højer herred, jvf. Ludwig Andresen: Geschichte der Stadt Tondern bis 1627,1939 , s. 8, og ikke - som antaget af J. Steenstrup - af Lø herred.

31. Af de herreder, de nævnte byer ligger i, fik kongen også told, og det tolkes som et vidnesbyrd om byernes eksistens.

32. 1240 og 1251 har Abel udstedt breve i Flensborg, hvor Skt. Nikolai-kvarteret på den tid udformedes.

33. Jvf. note 26 .

34. Danmarks gamle Købstadlovgivning, 1951, s. 3 ff.; Åbenrå Bys Historie, I, s. 26 ff.

35. Danmarks gamle Købstadlovgivning, 1951, s. 215-232. - Pudsigt nok er denne kopi den ældst kendte tekst af Lübecks stadsret. Alle paragraffer er blevet afskrevet, hvilket indebærer, at Tønders lybske stadsret også indeholder bestemmelser om lokale lybske forhold, f.eks. om sejlads på Trave-floden!

36. "... ob honorem et dilectionem domini Abel, illustris ducis Iucie, et ad instanciam et petitionem fratris Reinardi, ordinis fratrum minorum Dacie ministri, et eciam pro dilectione ciuium de Tundere ...«

37. „Für die Uebertragung des Lübischen Rechts nach Tondern wird wesentligch mitgewirkt haben, dass deutsche Kräfte hier schon führend geworden waren und ihr Wunsch mit dem politischen Willen des Herzogs Abel zusammentrafu (Ludwig Andresen: Geschichte der Stadt Tondern bis zum dreissigjährigen Krieg, 1939, s. 10).

38. "Nur Tondern war 1243 mit dem Lübischen Recht begabt worden; die Bildung dieser deutschen Rechtsinsel in Schleswig geht zweifellos auf einen frühen hansischen Vorstoss über die Eider zurück (Otto Brandt: Geschichte Schleswig-Holsteins, 6. oplag ved Wilhelm Klüver, 1966, s. 101).

39. "Als einzige Stadt des Herzogtums wurde Tondern bald nach seiner Neubegründung 1243 von Herzog Abel mit dem Lübischen Stadtrecht begabt, eine Tatsache, welche vermutlich auf deutsche Einflüsse bei der Stadtgründung hinweisen dürfte» (Erich Hoffmann: Die Herkunft des Bürgertums in den Städten des Herzogtums Schleswig, 1953, s. 154).

40. "Die Erteilung des Lübecker Stadtrechts an die Stadt Tondern nach der Ortserweiterung lässt ebenfalls eine Zusammenarbeit Herzog Abels mit der Genossenschaft einer deutschen "Nikolaikaufmannsgruppe « für möglich erscheinen « (Erich Hoffmann: Beiträge zur Geschichte der Stadt Schleswig, Zeitschrift d. Ges. f. Schlesw.Holsteinische Geschichte, 1980, bd. 105, s. 72).

41. Det er således en historieskrivning med usminket tendens, der kommer til orde $\mathrm{i}$ følgende sætning i Ludwig Andresens Geschichte der Stadt Tondern, s. 9: „Zu der 
gleichen Zeit ... mag Herzog Abel den Zuzug nach Tondern aus dem Umlande wie von Süden gefördert haben, nicht nur um die junge Siedlung gegen Konkurrenz durch das ältere, bischöflich-dänische Mögeltondern zu kräftigen, sondern auch um das hier schon vorhandene niederdeutsche Element zu stärken «. De her kursiverede ord viser, hvorledes den ellers særdeles habile Ludwig Andresen uden vaklen fremsatter postulater af nationalpolitisk art! Hvorfra kender han »et allerede forhåndenværende nedertysk element? « At han opfatter Møgeltønder som ældre i forhold til Tønder, er en helt anden sag og en fuldt legitim opfattelse. Jeg mener $i$ den herværende fremstilling at have givet en geografisk begrundelse for, at Tonder som folge af sin beliggenhed længst inde $i$ landet må være aldst, men den slags kan naturligvis diskuteres. Det kursiverede er derimod en politisk forhåndsopfattelse, som der ikke er belæg for.

42. H. V. Gregersen: Om baggrunden for Sydslesvigs fortyskning og for hjemmetyskheden i Nordslesvig (Sønderjysk Mănedsskrift, 1985, s. 175-182); sm.: Var Skt. Nikolai i Aabenraa en tysk købmandskirke? (Sønderjysk Månedsskrift, 1986, s. 112-121).

43. Jvf. note 26.

44. Jvf. note 27.

45. DD/DRB, 3. rk. I, nr. $11,36,39,40$.

46. DD/DRB, 3. rk., II, nr. 17.

47. Nævnt 1326, jvf. DD/DRB, 3. rk., IV, nr. 126.

48. DD/DRB, 3. rk., V, nr. 163 (med maglingsforslaget fra efteråret 1358, hvori holstenerne hævdede, at erobringen af Tønder ikke var en sag mellem dem og kongen, eftersom Tønder by og slot hørte hertugen til). Jvf. Ludwig Andresen: Geschichte der Stadt Tondern, s. 20.

49. DD/DRB, 2. rk., XII, nr. 96.

50. DD/DRB, 3. rk., VI, nr. 2.

51. DD/DRB, 3. rk., V, nr. 325.

52. Herom f.eks.: H. V. Gregersen: Plattysk i Sønderjylland, s. 110-112.

53. Schl.-Holst. Regesten u. Urkunden, VI, nr. 663.

54. E. J. v. Westphalen: Monumenta Inedita, IV, 1745, s. 3224, hvor det bl.a. hedder: n... dat Wy umme Truwe und Wolldaht, da dessülven unse Bulüde und Inwahner tho Lütcken Tundern by unsen Vorfahren und unsen Landen und Lüden in Vortyden gedahn hebben «. Jvf. Ludwig Andresen: Geschichte der Stadt Tondern, s. 24.

55. Se: Chr. L. E. v. Stemann: Geschichte des öffentlichen und Privat-Rechts, III, 1867, s. 51-55 (nr. 36); smlgn. Danske Magazin, 5. rk., IV, s. 362-363.

56. H. V. Gregersen: Plattysk i Sønderjylland, s. 220-240, spec. om Tønder: s. 230-231.

57. RA. De sønderjyske fyrstearkiver. Hans den Fldre, D 40 III; Rep Dipl, 2. rk., III, nr. 5763; Claus Rolfs: Geschichte des Fleckens Høyer, 1926, s. 521-522.

58. Th. O. Achelis: Beiträge zur Reformationsgeschichte (Genealogie, VI, 1962, s. 98. - Achelis korrigerer heri al hidtidig viden om Deckers fortid.

59. RA. De sønderjyske fyrstearkiver. Hans den Ældre, D 40 III; jvf. Plattysk i Sønderjylland, s. 288.

60. Se: Plattysk i Sønderjylland, s. 288-291.

61. Plattysk i Sønderjylland, s. 306-307.

62. Kgl. Bibl., Thott 1928 b, $4^{\circ}$; Sønderjyske Årbøger, 1963, s. 161-233.

63. Plattysk i Sønderjylland, s. $347 \mathrm{ff}$.

64. Plattysk i Sønderjylland, s. $308 \mathrm{ff}$. 
65. Frode Gribsvad: Hvad fortæller retsprotokollerne om retssproget i Nordslesvig (Afhandlinger tilegnede arkivmanden og historikeren, rigsarkivar, dr. phil. Axel Linvald, 1956, s. 122-128).

66. Se f.eks. H. V. Gregersen: Slesvig og Holsten indtil 1830, 1981, s. 352-364.

67. Se note 10.

68. H. V. Gregersen: Den Lüneburgske Saltoktroi. Et bidrag til salthandelens historie i hertugdømmet Slesvig, 1962.

69. Peter Kr. Iversen: Møgeltønder len (Sønderjyske Årbøger, 1943, s. 50-110); sm.: Herremand og bonde i Vestslesvig i 1660erne og 1670erne (Sønderjyske Årbøger, 1942, s. 58-109); sm.: Træk af Møgeltønders historie (Møgeltønder. Slotsby og bondeby, udg. Fredningsstyrelsen og Tønder kommune, 1985, s. 9-39).

70. H. V. Gregersen: Messe og Marked, 2. udg. 1974, s. 63-68.

71. Lorenz Rerup: Slesvig og Holsten efter 1830, 1982, s. 75-78.

72. Jvf, note 15 . 
